\title{
Growth and yield of seed potatoes after application of gibberellic acid to the tubers before planting
}

\author{
J. Marinus and K. B. A. Bodlaender \\ Centre for Agrobiological Research (CABO), Wageningen, the Netherlands
}

Accepted: 21 March 1978

Key words: seed potato, gibberellic acid, tuber treatment

\section{Summary}

The influence of gibberellic acid $\left(\mathrm{GA}_{3}, \mathrm{GA}\right)$ on growth and yield of seed (tuber size $28-45 \mathrm{~mm}$ ) was studied in field experiments on sandy soil in the late variety Alpha. Different GA concentrations were applied to seed with and without sprouts by both dipping and spraying.

The main purpose was to find a more suitable method of preparing the seed than the laborious 'presprouting in light' method. This other method should allow mechanical planting, should not be laborious and should give a high yield of seed tubers.

The application of GA accelerated emergence. GA also increased significantly the yield of the seed tuber fraction, probably by increasing the number of stems and thus the number of tubers per plant. GA accelerated tuberization, decreased the total tuber yields in one experiment, whereas in the other experiment an increase occurred. The best results were obtained if sprouted tubers were treated and under favourable growing conditions.

Spraying was equally effective as dipping also in the 'spraying just before planting' treatment after heat shock. This means that application during mechanical planting seems to be possible, on the understanding that the concentration is not too high to prevent the occurrence of GA characteristics ( $45 \mathrm{mg} /$ litre GA caused small leaflets with yellow discolouration).

The application of GA to seed tubers seems to be attractive especially in slowly emerging varieties or in varieties with a high proportion of large tubers.

\section{Introduction}

In the Netherlands seed potato crops are lifted early. To obtain a high yield of seed tubers emergence should be rapid. Therefore the seed tubers were formerly presprouted in light during several months at a relatively low temperature. This 'presprouting in light', however, is replaced more and more by methods less 


\section{EFFECT OF GA ON GROWTH AND YIELD OF SEED POTATOES}

laborious, for instance the 'heat shock': in this method the tubers are placed at a rather high temperature (c. $20^{\circ} \mathrm{C}$ ) during some days before planting. Emergence of plants from these tubers is slower than after presprouting in light and often gives a lower tuber yield. Therefore we tried to accelerate emergence by treating the seed with growth promoting substances.

In earlier experiments with different substances (ethefon, rindite, gibberellic acid, etc.) the best results were obtained by a treatment of the seed with gibberellic acid (GA). Other workers have also treated seed tubers with GA with varying results: the total tuber yields were sometimes influenced positively (Keller \& Bérces, 1964), sometimes negatively (Timm et al., 1962). The yield of the small tuber sizes mostly increased. Sometimes the different results can be explained by means of the properties of the varieties, lifting dates, GA concentrations used, etc. Often important data like the method of presprouting or the rate of germination of the tubers during the treatment with GA are lacking in the literature.

Most authors tried to influence with GA the dry matter distribution, final tuber yields, consumption value etc. The purpose of the experiments described in this paper, however, was to improve the production of seed. In this case tuber size distribution and total tuber yield are important. To attain this improvement GA was applied to seed without and with small sprouts; these sprouts do not break with mechanical planting. The effect of GA on emergence, foliage development and tuberization has also been studied.

\section{Methods}

\section{General design Exp. I and II}

In 1974 two experiments were carried out with the late, slowly emerging variety Alpha. In Exp. I the influence was studied of the GA concentrations (9, 22 $1 / 2$, $45 \mathrm{mg} /$ litre) and the method of application to the seed tubers (dipping and spraying) on foliage development, yield of seed and total tuber yield, with two methods of presprouting (no-presprouting and heat shock). In Exp. II a special study was made of how tuberization was influenced by application of GA to seed tubers (dipping in $22 \mathrm{I} / 2 \mathrm{mg} /$ litre solution), with three methods of presprouting (no presprouting, heat shock and presprouting in light). In both experiments each method of presprouting included also two controls, viz 'completely untreated' and 'dipping in water'. For comparison, 'untreated, presprouting in light' plots were added to Exp. I, because in earlier days this method was often used in practice.

\section{Methods of presprouting and $G A$ application}

The various methods of presprouting were carried out in the following ways (after storage at $4{ }^{\circ} \mathrm{C}$ in the dark):

- no presprouting: storage at $4{ }^{\circ} \mathrm{C}$ in the dark; the day before the application of GA the tubers were placed at room temperature;

- heat shock: storage during the last 6 days before application at $20{ }^{\circ} \mathrm{C}$ in the dark;

- presprouting in light: during the last $4 \frac{1}{2}$ weeks the tubers were kept at $16{ }^{\circ} \mathrm{C}$ 
Table 1. Number and average length of sprouts just before treating the tubers with GA.

\begin{tabular}{llc}
\hline $\begin{array}{l}\text { Method of } \\
\text { presprouting }\end{array}$ & $\begin{array}{l}\text { Number of sprouts } \\
\text { per tuber }\end{array}$ & $\begin{array}{l}\text { Length per sprout } \\
(\mathrm{mm})\end{array}$ \\
$\begin{array}{l}\text { No presprouting } \\
\text { Heat shock }\end{array}$ & $0^{\mathcal{1}}$ & 0 \\
Presprouting in light & 2.9 & 2.4 \\
\hline
\end{tabular}

$110 \%$ of the tubers had one sprout of $2 \mathrm{~mm}$ per tuber.

in continuous light (TFL 55 fluorescent tubes, light intensity 4500 lux).

The rates of sprouting on the day of applying GA are mentioned in Table 1.

One day before planting the tubers were either dipped during one hour in the solutions or sprayed completely wet (c. $2 \mathrm{mg}$ solution per tuber). A powder containing $90 \% \mathrm{GA}_{3}$ is used; in the tables and figures the concentrations of the active ingredient are mentioned.

\section{Planting and liftings}

The tubers (seed size $35-45 \mathrm{~mm}$ ) were planted by hand in a humous sandy soil in the eastern part of the Netherlands (50000 plants/ha). Exp. I was planted on 16 April and Exp. II two days later. The following liftings were carried out: in Exp. I on 30 July, in Exp. II there were two liftings during tuberization and a third one on 25 July. The plants were lifted by hand without haulm killing before.

\section{Results}

For all properties multiple range tests were carried out. The significance level was always $95 \%$. Significant effects of GA are mentioned in the text. For each characteristic first the general effects of GA will be mentioned and then the response of the plants to the GA concentrations, the method of application and the method of presprouting.

\section{Emergence}

The application of GA accelerated significantly the emergence in all the methods of presprouting except with the 'presprouting in light' plots in Exp. II, because too few data were available for the test. Complete emergence was also earlier in the GA plots than in the controls.

As the concentration was higher emergence was accelerated more (Fig. 1). Also dipping in water showed a slight possitive effect. In the same experiment spraying was more effective than dipping, especially with the heat shock method: heatshocked tubers sprayed with GA $22 \% / 2$ and $45 \mathrm{mg} /$ litre showed equally rapid emergence as the 'untreated presprouting in light' plots. In Exp. II (Fig. 2) emergence started earlier after application of GA, when the sprouts were longer (Table 1). Complete emergence was reached at an earlier date with GA than without GA; 


\section{EFFECT OF GA ON GROWTH AND YIELD OF SEED POTATOES}
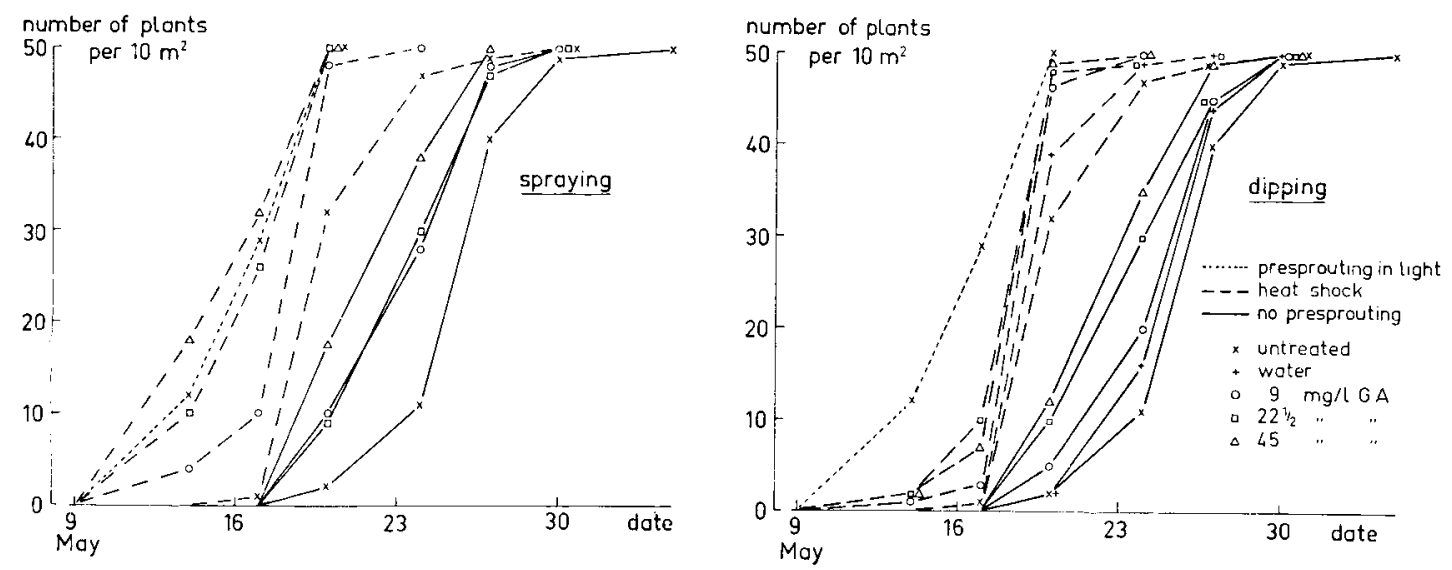

Fig. 1. Emergence of potato plants: effect of concentration and method of application of GA, with 2 methods of presprouting (Exp. I).

in the no presprouting plots this was less clear. In this experiment a treatment with water had hardly any effect.

\section{Soil cover}

Although GA accelerates emergence, this does not always mean that the date of complete soil cover by the foliage is attained at an earlier date. GA often promotes the formation of small leaflets, especially at high concentrations. For this reason soil cover can be influenced unfavourably. Therefore the degree of soil cover was estimated weekly by eye until the crop was closed $(=100 \%)$. Only for Exp. II a multiple range test was carried out.

In both experiments the rate of soil cover was increased by GA. Also treating with water caused in general an acceleration in soil cover.

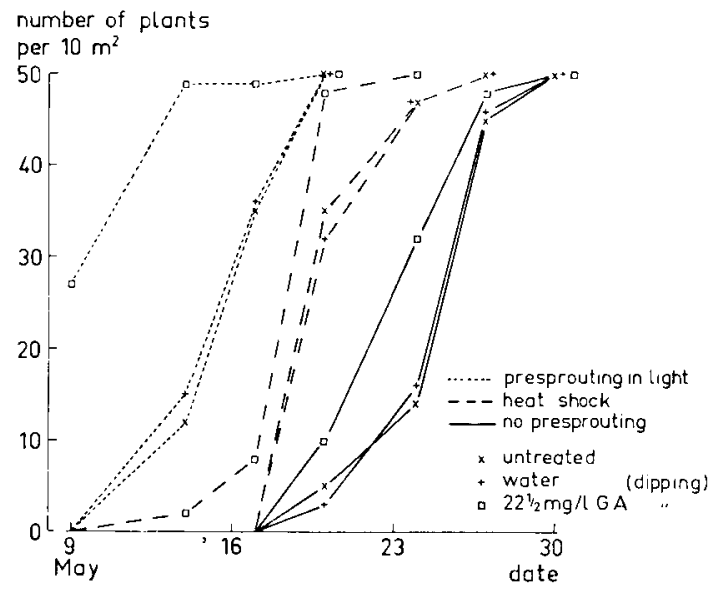

Fig. 2. Emergence of potato plants: effect of GA with 3 methods of presprouting (Exp. II). 

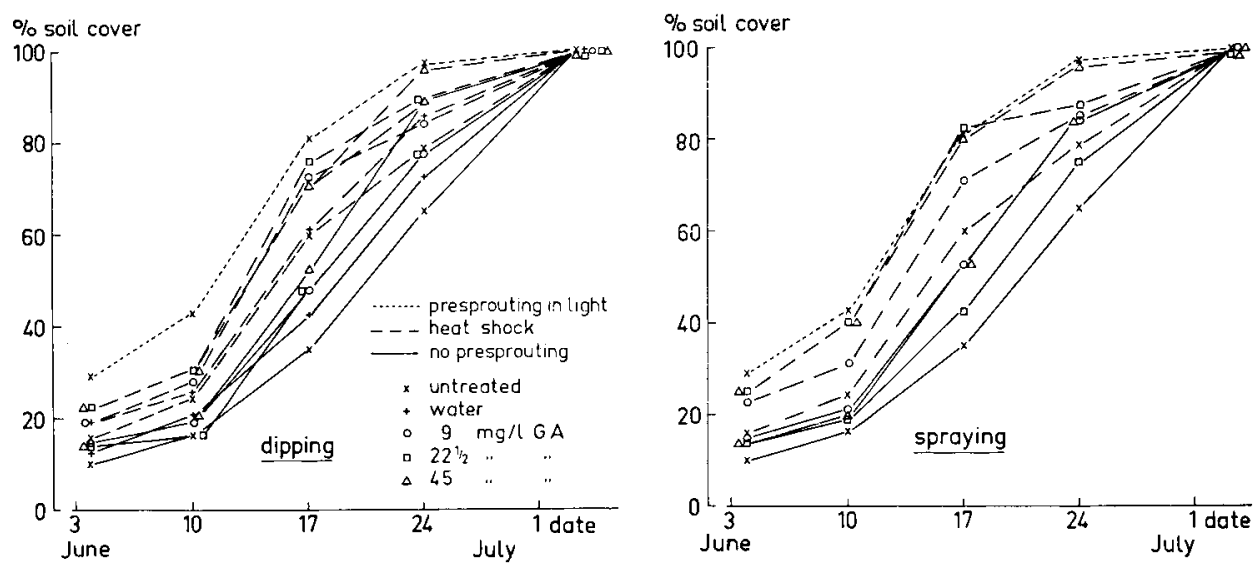

Fig. 3. Soil cover percentage of potato plants: effect of concentration and method of application of GA, with 2 methods of presprouting (Exp. I).

The effect of the GA concentration on the soil cover was less evident than on emergence (Fig. 3) for the reason mentioned above. When $45 \mathrm{mg} /$ litre GA was applied to the tubers after a heat shock the crop even closed at the same date as in the 'untreated presprouting in light' plots. The other GA plots attained a closed crop together somewhat later. Only in some cases spraying of GA appeared to increase the rate of soil cover more than dipping (for instance heat shock 22 $1 / 2$ and $45 \mathrm{mg}$ /litre GA and no presprouting $9 \mathrm{mg} /$ litre GA). The combined action of method of presprouting and aplication of GA was more evident in Exp. II (Fig. 4). Significant effects of GA were obtained in the methods of presprouting 'heat shock' and 'presprouting in light'; this was not the case with 'no presprouting' plots.

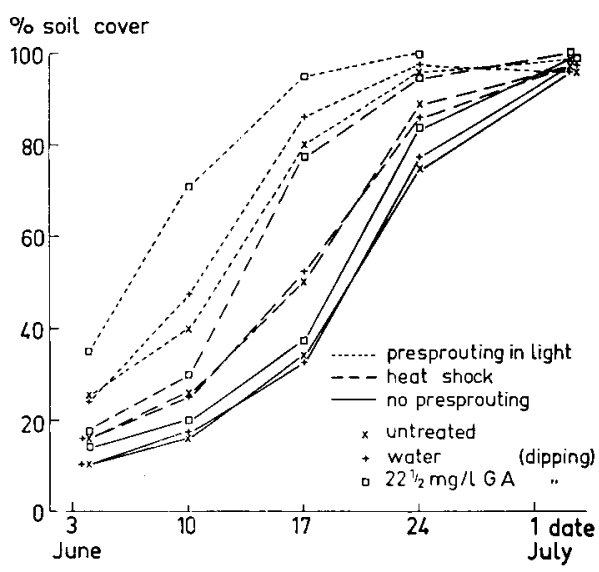

Fig. 4. Soil cover percentage of potato plants: effect of GA with 3 methods of presprouting (Exp. II). 
Table 2. Number of stems per $10 \mathrm{~m}^{2}$ : effect of GA concentration and method of application (Exp. I).

\begin{tabular}{llll}
\hline Treatments & No presprouting & Heat shock & Presprouting in light \\
Untreated & 209 & 183 & 228 \\
$\begin{array}{l}\text { Dipping } \\
\text { water }\end{array}$ & & \\
$9 \mathrm{mg} /$ litre GA & 232 & 194 & \\
$221 / 2 \mathrm{mg} /$ litre GA & 243 & 244 & \\
$45 \quad \mathrm{mg} /$ litre GA & 269 & 258 & \\
& & 304 & \\
Spraying & & \\
$9 \mathrm{mg} /$ litre GA & 277 & 233 & \\
$221 / 2 \mathrm{mg} /$ litre GA & 264 & 280 & \\
$45 \quad \mathrm{mg} /$ litre GA & 291 & 293 & \\
\hline
\end{tabular}

\section{Number of stems}

The application of GA increased the number of stems significantly except in the no presprouting plots + GA 9 and $221 / 2 \mathrm{mg} /$ litre in Exp. I. Mostly more stems occurred in the GA plots than in the 'presprouting in light' plots. Also dipping in water produced a slight increase in the number of stems.

Table 2 shows a greater numbers of stems as the GA concentrations were higher, although the differences were rather small sometimes. Especially in the 'no presprouting' method spraying was more effective than dipping. The numbers of stems in Exp. II (Table 3) are averages of the three liftings. Treating tubers with sprouts resulted in a higher response of the plants to GA than treating tubers without sprouts.

It was remarkable that small differences occurred between the untreated controls of the various methods of presprouting. Dipping in water increased significantly the number of stems with the 'presprouting in light' method.

\section{Tuberization and number of tubers}

In the liftings of Exp. II all tuber initiations $(\leqslant 5 \mathrm{~mm})$ and tubers $(>5 \mathrm{~mm})$ were counted. By summarizing these numbers the numbers of initiated tubers were obtained (Table 4).

Application of GA increased distinctly the number of initiated tubers with the various methods of presprouting and resulted in a greater number than in the 'untreated presprouting in light' plots. This increase was significant with the 'pre-

Table 3. Number of stems per $10 \mathrm{~m}^{2}$ : effect of $\mathrm{GA}$ with 3 methods of presprouting (Exp. II).

\begin{tabular}{llll}
\hline Treatments & No presprouting & Heat shock & Presprouting in light \\
Untreated & 214 & 191 & 210 \\
Water & 220 & 206 & 256 \\
$221 / 2 \mathrm{mg} /$ litre GA & 238 & 298 & 340 \\
\hline
\end{tabular}


Table 4. Total number of initiated tubers ( $=$ tuber initiations + tubers) and number of tubers per $10 \mathrm{~m}^{2}$ : effect of GA with 3 methods op presprouting at 3 lifting dates (Exp. II).

\begin{tabular}{|c|c|c|c|c|c|c|}
\hline \multirow[t]{2}{*}{ Treatments } & \multicolumn{3}{|c|}{ Number of initiated tubers } & \multicolumn{3}{|c|}{ Number of tubers } \\
\hline & 17 June & 24 June & 25 July & 17 June & 24 June & 25 July \\
\hline \multicolumn{7}{|l|}{ No presprouting } \\
\hline untreated & 240 & 710 & 109 & 35 & 571 & 650 \\
\hline water & 288 & 813 & 735 & 25 & 630 & 673 \\
\hline $221 / 2 \mathrm{mg} /$ litre GA & 401 & 934 & 870 & 108 & 656 & 758 \\
\hline \multicolumn{7}{|l|}{ Heat shock } \\
\hline untreated & 453 & 801 & 708 & 263 & 609 & 627 \\
\hline water & 431 & 856 & 759 & 202 & 633 & 669 \\
\hline $221 / 2 \mathrm{mg} /$ litre GA & 774 & 1148 & 931 & 441 & 805 & 820 \\
\hline \multicolumn{7}{|l|}{ Presprouting in light } \\
\hline untreated & 860 & 1028 & 747 & 652 & 779 & 688 \\
\hline water & 911 & 1125 & 833 & 669 & 802 & 736 \\
\hline $221 / 2 \mathrm{mg} /$ litre GA & 1204 & 1256 & 1042 & 835 & 916 & 959 \\
\hline
\end{tabular}

sprouting in light' and the 'heat shock' methods. Also dipping in water increased the number of initiated tubers. Moreover the impression was gained that by GA treatment tuberization was finished more quickly: the increase in number of initiated tubers from 17 till 24 June was smaller in the GA plots than in the controls. In all comparable treatments the number of initiated tubers increased as the sprouts during the GA application were longer.

Generally the tubers showed the same reaction as the initiated tubers.

\section{Total tuber yield}

The difference in response to the GA treatments between both experiments was remarkable: yields increased in Exp. I and decreased in Exp. II. The effect of GA was not significant in both trials.

There was no clear relation between the tuber yields and the GA concentration (Table 5). The optimum concentration seemed to depend on the method of presprouting (sprout length) and the method of applying GA. In general, spraying increased the yields more than dipping. In Exp. II GA did not influence the tuber yield in the 'no presprouting' plots, whereas in the other methods of presprouting the total tuber yields were decreased by GA (Table 6).

\section{Tuber size distribution and yield of seed $(28-45 \mathrm{~mm})$}

The yields of seed tubers were significantly increased by the GA treatments. These results are due to a change in the tuber size distribution in favour of the smaller sizes (35-45 $\mathrm{mm}$ and smaller) and at the cost of the larger sizes $(45-55 \mathrm{~mm}$ and larger). For this reason also the percentage of seed in the total yield increased. All the GA applications caused higher yields of seed than the 'untreated presprouting in light' plots. 


\section{EFFECT OF GA ON GROWTH AND YIELD OF SEED POTATOES}

In general the effect was greater as the GA concentration was higher, especially when GA was applied after a heat shock (Table 5). Spraying was more effective than dipping in comparable concentrations.

Similar effects of GA applications were obtained in Exp. II (Table 6). In spite of the unfavourable effect of GA on the total tuber yields with two methods of presprouting the yields of seed were increased by GA.

It was striking that the two controls treated with a heat shock yielded less seed tubers than all other treatments in Exp. II.

\section{Other observations}

In later experiments results similar to those in 1974 have been achieved in the varieties Alpha and Jaerla. The response of Bintje to GA was less favourable: many harvested tubers were too small for seed tuber purposes.

In other years, at low temperatures or after long dry periods, the response of the plants to GA was less pronounced. Especially differences in soil cover and in number of stems did not occur.

Table 5. Total tuber yield, tuber size distribution and yield of seed: effect of GA concentra. tion and method of application (Exp. I).

\begin{tabular}{|c|c|c|c|c|c|c|c|c|}
\hline \multirow{2}{*}{$\begin{array}{l}\text { Presprouting } \\
\text { and treatments }\end{array}$} & \multicolumn{6}{|c|}{ Tuber weight $\left(\mathrm{kg} / 10 \mathrm{~m}^{2}\right)$} & \multicolumn{2}{|c|}{ Yield of seed $28-45 \mathrm{~mm}$} \\
\hline & total & $<28$ & $28-35$ & $35-45$ & $45-55$ & $>55 \mathrm{~mm}$ & in $\mathrm{kg} / 10 \mathrm{~m}^{2}$ & $\begin{array}{l}\text { as \% of } \\
\text { total yield }\end{array}$ \\
\hline \multicolumn{9}{|l|}{ No presprouting } \\
\hline $\begin{array}{l}\text { Untreated } \\
\text { Dipping }\end{array}$ & 25.3 & 1.1 & 2.2 & 9.0 & 12.2 & 0.8 & 11.2 & 44.3 \\
\hline water & 25.3 & 1.2 & 2.9 & 10.5 & 10.3 & 0.4 & 13.4 & 53.0 \\
\hline $9 \mathrm{mg} /$ litre GA & 28.9 & 1.2 & 3.3 & 13.9 & 10.2 & 0.3 & 17.2 & 59.5 \\
\hline $221 / 2 \mathrm{mg} /$ litre GA & 27.9 & 1.6 & 4.0 & 14.3 & 7.7 & 0.3 & 18.3 & 65.6 \\
\hline $45 \mathrm{mg} /$ litre GA & 25.1 & 1.8 & 4.3 & 14.4 & 4.6 & 0.0 & 18.7 & 74.5 \\
\hline \multicolumn{9}{|l|}{ Spraying } \\
\hline $9 \mathrm{mg} /$ litre GA & 28.3 & 1.7 & 3.8 & 14.5 & 8.1 & 0.2 & 18.3 & 64.6 \\
\hline $221 / 2 \mathrm{mg} /$ litre GA & 29.0 & 1.4 & 3.3 & 14.5 & 9.8 & 0.0 & 17.8 & 61.4 \\
\hline $45 \mathrm{mg} /$ litre GA & 29.8 & 1.6 & 4.1 & 15.7 & 8.4 & 0.0 & 19.8 & 66.3 \\
\hline \multicolumn{9}{|l|}{ Heat shock } \\
\hline \multicolumn{9}{|l|}{ Dipping } \\
\hline water & 29.5 & 0.6 & 1.8 & 9.2 & 15.9 & 2.0 & 11.0 & 37.3 \\
\hline $9 \mathrm{mg} /$ litre GA & 32.1 & 0.8 & 2.9 & 12.8 & 14.7 & 0.9 & 15.7 & 48.9 \\
\hline $221 / 2 \mathrm{mg} /$ litre GA & 32.6 & 1.2 & 3.6 & 15.1 & 12.7 & 0.0 & 18.7 & 57.3 \\
\hline $45 \mathrm{mg} /$ litre GA & 32.8 & 1.4 & 4.0 & 16.5 & 10.5 & 0.4 & 20.5 & 62.5 \\
\hline \multicolumn{9}{|l|}{ Spraying } \\
\hline $9 \mathrm{mg}$ /litre GA & 37.7 & 0.8 & 2.2 & 14.4 & 19.1 & 1.2 & 16.6 & 44.0 \\
\hline $221 / 2 \mathrm{mg} /$ litre $\mathrm{GA}$ & 34.8 & 1.2 & 3.5 & 16.4 & 13.5 & 0.2 & 19.9 & 57.2 \\
\hline $45 \mathrm{mg} /$ litre GA & 33.5 & 1.5 & 3.9 & 16.7 & 11.4 & 0.0 & 20.6 & 61.4 \\
\hline \multicolumn{9}{|c|}{ Presprouting in light } \\
\hline Untreated & 39.2 & 0.7 & 2.3 & 10.9 & 22.6 & 2.7 & 13.2 & 33.7 \\
\hline
\end{tabular}


Table 6. Total tuber yield, tuber size distribution and yield of seed: effect of GA with 3 methods of presprouting (Exp. II).

\begin{tabular}{|c|c|c|c|c|c|c|c|c|}
\hline \multirow{2}{*}{$\begin{array}{l}\text { Presprouting } \\
\text { and treatments }\end{array}$} & \multicolumn{6}{|c|}{ Tuber weight $\left(\mathrm{kg} / 10 \mathrm{~m}^{2}\right)$} & \multicolumn{2}{|c|}{ Yield of seed $28-45 \mathrm{~mm}$} \\
\hline & total & $<28$ & $28-35$ & $35-45$ & $45-55$ & $>55 \mathrm{~mm}$ & in $\mathrm{kg} / 10 \mathrm{~m}^{2}$ & $\begin{array}{l}\text { as } \% \text { of } \\
\text { total yield }\end{array}$ \\
\hline \multicolumn{9}{|l|}{ No presprouting } \\
\hline $\begin{array}{l}\text { untreated } \\
\text { water }\end{array}$ & $\begin{array}{l}25.2 \\
26.2\end{array}$ & $\begin{array}{l}0.8 \\
0.9\end{array}$ & $\begin{array}{l}2.0 \\
2.3\end{array}$ & $\begin{array}{l}11.1 \\
10.4\end{array}$ & $\begin{array}{l}10.9 \\
12.0\end{array}$ & $\begin{array}{l}0.4 \\
0.6\end{array}$ & $\begin{array}{l}13.1 \\
12.7\end{array}$ & $\begin{array}{l}52.0 \\
48.4\end{array}$ \\
\hline $221 / 2 \mathrm{mg} /$ litre GA & 25.2 & 1.1 & 2.9 & 14.0 & 6.6 & 0.6 & 16.9 & 67.1 \\
\hline \multicolumn{9}{|l|}{ Heat shock } \\
\hline untreated & 31.8 & 0.5 & 1.5 & 8.8 & 18.3 & 2.7 & 10.3 & $\begin{array}{l}32.4 \\
387\end{array}$ \\
\hline water & 28.2 & 0.7 & 2.0 & 8.9 & 14.8 & 1.8 & 10.9 & 38.7 \\
\hline $221 / 2 \mathrm{mg} /$ litre GA & 27.7 & 1.1 & 3.6 & 13.3 & 9.7 & 0.0 & 16.9 & 61.0 \\
\hline \multicolumn{9}{|c|}{ Presprouting in light } \\
\hline untreated & 36.3 & 0.6 & 2.1 & 9.9 & 22.0 & 1.7 & 12.0 & 33.1 \\
\hline water & 34.1 & 0.8 & 2.2 & 11.8 & 17.1 & 2.2 & 14.0 & 41.1 \\
\hline $22 \frac{1}{2} \mathrm{mg} /$ litre GA & 31.5 & 1.6 & 5.2 & 17.5 & 7.2 & 0.0 & 22.7 & 72.1 \\
\hline
\end{tabular}

In a view of a possible application of GA with mechanical planting of tubers an extra treatment was added to Exp. I: $221 / 2 \mathrm{mg} / \mathrm{litre}$ GA was sprayed on tubers pretreated with a heat shock just before planting. The tubers were wet when they were planted. In this treatment there was a retardation in emergence compared with application the day before planting. However between these treatments there were no differences in number of stems, and the differences in seed yields and in total tuber yields were rather small. These results indicate that mechanical planting seems to be practicable.

Moreover, in the progeny we found hardly any unfavourable after-effect of GA on the total tuber yields in an experiment with Alpha and Jaerla.

\section{Discussion}

Application of GA to seed tubers promoted distinctly the emergence of the plants and increased significantly the yield of seed. However the total tuber yields were influenced differently in both experiments.

Also in the relevant literature conflicting evidence is found, and this means that it is not easy to obtain a clear picture of the working mechanism of GA in the potato plant.

Possible causes for the variations in the results are the following:

- the penetration of GA in the tubers. This occurs easier in tubers with sprouts than in those without sprouts; in Exp. II the greatest responses to GA were obtained with the presprouting methods 'heat shock' and 'presprouting in light': This observation corresponds with the results of Hansen (1973) with Bintje. However the results of Timm et al. (1962), with three varieties, and of Kapoor (1971), also 
working with Bintje and some other varieties, were just the opposite. Possibly the age of the tubers during the applications of GA also influences the results. - the climate conditions. It seems that favourable growing conditions promote the effect of GA. This explains the different results in the various years, which is corroborated by the results of Timm et al. $(1960,1962)$ and Keller \& Bérces (1964).

- the variety. In our experiments the response of Bintje to GA was less evident than that of Alpha. However, in both varieties the response was positive with respect to more and smaller tubers.

Other authors also studied the influence of GA on emergence and some found little or no influence (van Hiele, 1961) or even a negative response (Hansen, (1973).

These factors must be taken into account in discussing the results of our experiments.

GA increased mostly the number of stems. With the same variety (Bintje) and concentration ( $5 \mathrm{mg} /$ litre GA) such an increase in the number of stems was also found by Hansen (1973) and Perennec \& Crosnier (1971) by dipping in GAcontaining solutions, whereas Keller \& Bérces (1964) found no clear increase after spraying. Possibly the penetration of GA in the tubers was influenced by the method of application.

In many experiments the application of GA retarded tuberization (Claver, 1960; Okazawa, 1959; Timm et al., 1962). Also with stem cuttings of Solanum andigena grown under short day, retarded tuberization was found after application of GA (Kumar \& Wareing, 1974). This contradicts our results in which faster tuberization occurred after application of GA. As emergence and number of stems was also promoted, resulting in earlier soil cover by the foliage, it may be suggested that the favourable conditions for potato growth during the experimental season of 1974 may have promoted foliage growth to such an extent that the adverse effect of GA on tuberization was nullified.

The significant increase in seed yields $(28-45 \mathrm{~mm})$ with the GA applications was caused by a shift in favour of the small tuber sizes. This shift was due to an increase in number of tubers. The number of tubers per stem was not influenced by GA in Exp. II. The results of Smeltzer \& Mackay (1963) also showed a distinct correlation between number of stems and number of tubers. Other workers often found more stems and smaller tubers after GA applications than in the controls. Apparently by GA the apical dominance disappeared.

In all GA applications in Exp. II larger yields of seed were harvested than in the controls, irrespective of the method of presprouting. Even the "no presprouting plus GA' plots produced higher yields than all the controls despite of the low total tuber yields. The highest yield was obtained with "presprouting in light plus GA'. This combination of presprouting and GA can be useful in some cases, for example when small amounts of seed are available.

The total tuber yields were influenced positively in Exp. I and mostly negatively in Exp. II. In the light of the slight differences in growing conditions and growth periods these differences can hardly be explained. Also in the literature different 
results are mentioned: in the variety Bintje, Kapoor (1971) found, 77 days after planting, a decrease in the tuber yield of $16 \%$ at the low concentration of 5 $\mathrm{mg}$ /litre GA, whereas in experiments of Keller \& Bérces (1964), with the same variety and concentrations of $1 / 2,1$ and $5 \mathrm{mg} /$ litre $\mathrm{GA}$, but at a lifting date, the yields were 7 to $10 \%$ higher than in the controls. In other experiments we mostly found a decrease in the tuber yield at the final liftings. So the increase or decrease in the total tuber yields is not due to differences in development stage (lifting dates), but presumably influenced by the factors discussed before.

In seed potato production no malformations of the leaves should occur, because these make it impossible to select and consequently remove the plants with virus diseases from the field. With high concentrations of GA the leaves of the plants may show the typical GA characteristics during a long period (small and discoloured leaflets). Therefore a concentration of $45 \mathrm{mg} /$ litre GA is too high.

The 'presprouting in light' controls, compared with all treatments of the other methods of presprouting, showed faster emergence, more rapid tuberization and higher total yields. Nevertheless all GA applications produced much higher yields in the seed size fractions by a shift in tuber size distribution.

With regard to the yield of seed, GA applications were very successful, but due care should be taken with its use in practice. General instructions for practical use cannot as yet be given.

In so far as we know, application by spraying is equally effective as dipping and can be combined with mechanical planting. Breaking of the sprouts must be prevented to avoid too much branching of the bases of these sprouts (too many stems).

Further research has to be carried out to study the relations between the speed of development and lifting date. A rapidly developing crop probably has to be harvested earlier than a slowly growing crop, because otherwise the harvested tubers are too big. Crop analysis is necessary to study tuberization, realization of the tuber sizes and tuber yield.

\section{References}

Claver, F. K., 1960. Effectos del ácido giberélico y de la hidrazida maleic sobre la tuberización de la papa. Phyton. 15: 29-35.

Hansen, Sv. E., 1973. Forsøg med planteafstande, knolstørrelser og vaekstofbehandling ved kartoffelavl. Tidskr. Planteavl. 77: 61-70.

Hiele, F. J. H. van, 1961. Unsprouted potato tubers treated with gibberellic acid (GA $\left.\mathbf{A}_{3}\right)$. Eur. Potato J. 4: 26-39.

Kapoor, J. K., 1971. The effect of gibberellic acid treatment on tuber size, number and total yield. Rep. Ser. TMF No 620. Agricultural Division, ICI Plant Protection Ltd.

Keller, E. R. \& S. Bérces, 1964. Über die Auswirkungen der Behandlung vorgekiemter Kartoffelknollen mit Gibberellinsäure. Schweiz. landw. Forsch. 4 (3) 59-66.

Kumar, D. \& P. F. Wareing, 1974. Studies on tuberization of Solanum andigena. II. Growth hormones and tuberization. New Phytol. 73: 833-840.

Okazawa, Y., 1959. Studies on the occurrence of natural gibberellin and its effects on the tuber formation of potato plants. Proc. Crop. Sci. Japan 28: 129-133.

Perennec, P. \& J. C. Crosnier, 1971. Action d'un traitement des plantes de pomme de terre 


\section{EFFECT OF GA ON GROWTH AND YIELD OF SEED POTATOES}

par l'acide gibbérellique sur le rendement et la repartition dans la récolte des tubercules de divers calibres. Pomme de Terre fr. 33: 21-35.

Smeltzer, G. G. \& D. C. Mackay, 1963. The influence of gibberellic acid seed treatment and seed spacing on yield and tuber size of potatoes. Am. Potato J. 40: 377-380.

Timm, H., L. Rappaport, P. Primer \& O. E. Smith, 1960. Sprouting, plant growth and tuber production as affected by chemical treatment of white potato seed pieces. II. Effect of temperature and time of treatment with gibberellic acid. Am. Potato J. 37: 357-365.

Timm, H., L. Rappaport, S. C. Bishop \& B. J. Hoyle, 1962. Sprouting, plant growth and tuber production as affected by chemical treatment of white potato seed pieces. IV. Response of dormant and sprouted seed tubers to gibberellic acid. Am. Potato J. 39: 107-115. 